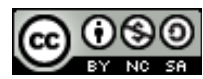

https://doi.org/10.31743/abmk.11411

ROLAND PREJS OFMCap.* - LUBLIN

\title{
ZANIK OBECNOŚCI ZAKONNIKÓW FRANCISZKAŃSKICH W DIECEZJI SANDOMIERSKIEJ PO 1864 ROKU
}

\begin{abstract}
Streszczenie
Władze carskie dokonały w 1864 r. kasaty klasztorów w Królestwie Polskim. W diecezji sandomierskiej zostały skasowane klasztory: Bernardynów w Kazanowie, Opatowie i Radomiu, Franciszkanów konwentualnych w Smardzewicach i Zawichoście oraz Franciszkanów-Reformatów w Rytwianach, Sandomierzu i Solcu. Nie został skasowany klasztor Bernardynów w Paradyżu (Wielkiej Woli). W 1870 r. władze carskie przesiedliły Reformatów z klasztoru w Jędrzejowie (diecezja kielecka) do klasztoru w Wysokim Kole. Tak więc na terenie diecezji ostatecznie były dwa klasztory franciszkańskie zachowane od kasaty: Bernardynów w Paradyżu i Reformatów w Wysokim Kole. Liczba zakonników systematycznie się zmniejszała z powodu zgonów, zakazu przyjmowania nowicjuszy oraz przechodzenia niektórych zakonników do pracy duszpasterskiej w parafiach. To sprawiło, że klasztor w Wysokim Kole przestał istnieć z chwilą śmierci ostatniego zakonnika w 1891 r., a klasztor w Paradyżu został za-mknięty w 1893 r. W 1899 r. zmarli dwaj dawni bernardyni, którzy w tym czasie byli już se-kularyzowani i pracowali w duszpasterstwie parafialnym jako księża diecezji sandomierskiej. Na nich zakończyła się obecność dawnych zakonników, którzy zostali sekularyzowani. Przy kościołach klasztorów skasowanych w 1864 r. władze carskie zostawiały jednego lub dwóch zakonników dla odprawiania nabożeństw. Ostatni z takich zakonników zmarł w 1911 r. i z tą chwilą zakończyła się obecność zakonników franciszkańskich w diecezji sandomierskiej.
\end{abstract}

Słowa kluczowe: kasata klasztorów; diecezja sandomierska; bernardyni; franciszkanie; reformaci

\footnotetext{
* Roland Prejs OFMCap - prof. dr hab. historii Kościoła, Sekcja Historii Kościoła i Patrologii, Katolicki Uniwersytet Lubelski Jana Pawła II

e-mail: roland@kul.pl

https://orcid.org/0000-0002-4412-3315
} 
Nocą z 27 na 28 listopada 1864 r. władze carskie w Królestwie Polskim przeprowadziły kasatę klasztorów jako formę represji za rzeczywisty lub domniemany udział zakonników w powstaniu styczniowym. Nazwano ją dość przewrotnie „reformą", powołując się na postanowienia soboru trydenckiego, który wymagał do istnienia klasztoru określonej liczby zakonników i spełnienia warunków zapewniających prowadzenie regularnego życia zakonnego. Podstawą do owej „reformy" był ukaz cara Aleksandra II z 8 listopada 1864 r., w myśl którego klasztory podzielono na cztery kategorie: 1) zniesione (te, w których przebywało mniej niż 8 zakonników); 2) zamknięte (te, których członkom udowodniono udział w „buncie"); 3) nieetatowe (miały prawo istnienia do śmierci ostatniego zakonnika; nie miały prawa przyjmowania nowicjuszów);4) etatowe (miały prawo istnienia i przyjmowania nowicjuszów, ale to ostatnie mogło nastąpić dopiero wtedy, gdy liczba zakonników spadła poniżej 14 i nie istniał już żaden klasztor nieetatowy tego zakonu, a taki istniał, z jego składu miano uzupełniać niedobór personalny w klasztorze etatowym). Zakonników z klasztorów zniesionych i zamkniętych zwożono do klasztorów etatowych. Ukaz carski znosił ponadto zwierzchnie władze zakonne (prowincjałów, kapituły, definitoria), zabraniał kontaktu z generałami zakonnymi w Rzymie i poddawał klasztory jurysdykcji ordynariusza miejsca, który do bezpośredniego zwierzchnictwa nad klasztorami miał ustanowić tzw. wizytatora klasztorów (urząd nieznany ówczesnemu prawu kanonicznemu).

Łatwo zauważyć, że „reforma” klasztorów miała w gruncie rzeczy na celu likwidację życia zakonnego w Królestwie Polskim, tyle że rozłożoną w czasie. Można było wprawdzie skazać wszystkich zakonników na banicję lub zesłać na Syberię, do czego zresztą pretekst by się znalazł, względnie zastosować jeszcze inne środki powodujące natychmiastową likwidację zakonów, władzom carskim jednak chodziło o pozory, że jest to rzeczywiście „reforma”, mająca - jak głosiła propaganda - sprowadzić zakonników na właściwą im drogę powołania, a oderwać od knowań i buntów przeciwko prawowitej władzy릴.

\footnotetext{
${ }^{1} \mathrm{Na}$ temat ukazu carskiego o „reformie” klasztorów i jego realizacji zob. m.in.: W. Wójcik, Tak zwana reforma klasztorów w 1864 roku na terenie diecezji sandomierskiej, „Archiwa Biblioteki i Muzea Kościelne”, 23 (1971) s. 343-360; A. Petrani, Kasata domów zakonnych w Warszawie w 1864 roku w świetle źródet rosyjskich, „Prawo Kanoniczne”, 15 (1972) nr 1-2, s. 267-275; S. Gajewski, Kasata klasztorów w diecezji lubelskiej w roku 1864, „Roczniki Humanistyczne”, 21 (1973) z. 2, s. 351-390; J. Kałowski, Uprawnienia nad zakonami udzielone biskupom przez Stolicę Apostolska po 1864 r., „Prawo Kanoniczne”, 20 (1977) nr 1-2, s. 137-149; M.M. Grzybowski, Postawa Wincentego Chościak-Popiela, biskupa płockiego, wobec kasaty klasztorów z 1864 r. w jego diecezji, „Studia Płockie", 11 (1983) s. 257-272; E. Orzechowska, Własność poklasztorna w diecezji sandomierskiej po ukazie z 8 XI 1864 r., „Roczniki Humanistyczne”, 31 (1983) z. 2, s. 187-212; P.P. Gach, Kasaty zakonów na ziemiach dawnej Rzeczypospolitej i Śląska 1773-1914, Lublin 1984; A.J. Szteinke, Kościót Świętego Antoniego i klasztor Franciszkanów-Reformatów w Warszawie 1623-1987, Kraków 1990; P.P. Gach, Zakony franciszkańskie na ziemiach dawnej Rzeczypospolitej i Śląska w latach 1773-1914, w: Zakony franciszkańskie w Polsce, t. 3: Franciszkanie w Polsce XIX wieku, Niepokalanów 1996, s. 11-56; E. Orzechowska, Z działalności patriotycznej bernardynów w Radomiu $w$ dobie powstania styczniowego (1861-1864), w: Zakony franciszkańskie w Polsce, s. 149-161; M. Budziarek, Realizacja ukazu cesarskiego z 8 XI 1864 wobec klasztoru kapucynów w Lublinie, w: Zakony franciszkańskie w Polsce, s. 163-176.
} 
$\mathrm{Na}$ terenie diecezji sandomierskiej w $1864 \mathrm{r}$. istniały męskie klasztory franciszkańskie²: Bernardynów w Kazanowie, Opatowie, Paradyżu (Wielkiej Woli) i Radomiu, Franciszkanów konwentualnych w Smardzewicach i Zawichoście oraz Reformatów w Rytwianach (dawny erem kamedułów), Sandomierzu i Sol$\mathrm{cu}^{3}$. Nie było na terenie diecezji klasztoru Kapucynów. Spośród tych klasztorów tylko klasztor Bernardynów w Paradyżu został uznany za etatowy, pozostałe zlikwidowano, za nieetatowy bowiem nie uznano żadnego klasztoru. Zakonnicy ze zlikwidowanych klasztorów zostali wywiezieni w następujących kierunkach: Bernardyni z Kazanowa, Opatowa i Radomia zostali skierowani do Paradyża, Franciszkanie ze Smardzewic i Zawichostu - do Kalisza (diecezja kujawsko-kaliska), Reformaci z Rytwian i Sandomierza - do Stopnicy (diecezja krakowsko-kielecka), Reformaci z Solca - do Jędrzejowa (diecezja krakowsko-kielecka) ${ }^{4}$.

W 1870 r. władze carskie przeniosły Reformatów z klasztoru etatowego w Jędrzejowie (diecezja krakowsko-kielecka) do klasztoru podominikańskiego w Wysokim Kole. Klasztor Reformatów w Wysokim Kole był odtąd traktowany jako etatowy. W diecezji sandomierskiej zaistniała sytuacja, że liczba klasztorów etatowych po kilku latach zwiększyła się ${ }^{5}$.

W artykule przedstawione zostaną skutki kasaty, wyrażające się w zmniejszeniu liczby zakonników, a ostatecznie w zupełnym zanikaniu ich obecności. Diecezja sandomierska została wybrana do rozważań jako typowa. W myśl ukazu kasacyjnego większość franciszkańskich klasztorów etatowych znalazła się w diecezji kieleckiej i kujawsko-kaliskiej, prawie zaś nie było ich w diecezji lubelskiej. Diecezja sandomierska jawi się więc jako ta, w której procesy pokasacyjne rozgrywały się w sposób w pewnym sensie reprezentatywny dla Królestwa Polskiego.

Kasata klasztorów - wbrew pozorom - nie była równoznaczna z zanikiem obecności zakonników: jedni pozostali w klasztorach etatowych i nieetatowych, inni trwali jako rektorzy kościołów poklasztornych, inni wreszcie - przynajmniej przez jakiś czas - jako duszpasterze parafialni. Zanik obecności zakonników nastąpił później. Materiały do interesującego nas zagadnienia znajdują się głównie w Archiwum Diecezjalnym w Sandomierzu. Są to niesygnowane poszyty, zatytułowane: „Akta wizytatora klasztorów Dyecezyi Sandomierskiej t. s. Klasztoru

${ }^{2}$ Założony przez św. Franciszka z Asyżu Zakon Braci Mniejszych na skutek różnych interpretacji tej samej reguły podzielił się w ciągu wieków na odrębne zakony: Braci Mniejszych Obserwantów, Braci Mniejszych Konwentualnych i Braci Mniejszych Kapucynów. Dodatkowo obserwanci dzielili się na tzw. rodziny, m.in. obserwantów (w Polsce zwanych bernardynami) i reformatów. Por.: H.E. Wyczawski (red.), Krótka historia Zakonu Braci Mniejszych, w: Klasztory bernardyńskie w Polsce w jej granicach historycznych, Kalwaria Zebrzydowska 1985, s. 581-631; L. Iriarte, Historia franciszkanizmu, Kraków 1998, passim.

${ }^{3}$ Schematismus ecclesiarum et cleri dioecesis sandomiriensis pro anno Domini 1864, [Sandomierz 1863], s. 76-80 (dalej: Schem. Sandom. z podaniem roku).

${ }^{4}$ Archiwum Archidiecezjalne w Lublinie (dalej: ArLb), sygn. 60 XI 33, Spis klasztorów zniesionych i zamkniętych z wyszczególnieniem, do jakich klasztorów przenoszą się z nich zakonnicy i z określeniem w przybliżeniu liczby tych ostatnich (drukowany wykaz, doręczony oficerom kierującym przebiegiem kasaty oraz przesłany do wiadomości rządcom diecezji).

${ }^{5}$ Archiwum Diecezjalne w Kielcach (dalej: ArKi), sygn. OK 20/7, k. 249-251v. 
XX. Bernardynów w Wielko-Woli 1865-1877”, „Akta Konsystorza Jeneralnego Dyecezyi Sandomierskiej t. s. Klasztoru XX. Bernardynów w Wielko-Woli 18711902"7, „Akta wizytatora klasztorów Dyecezyi Sandomierskiej t. s. Klasztoru OO. Reformatów w Wysokim Kole 1864-1878”, „Akta Konsystorza Jeneralnego Dyecezyi Sandomierskiej Ks. Ks. Reformatów w Wysokim Kole 1870-1893”, „Akta Konsystorza Jeneralnego Dyecezyi Sandomierskiej Zakonników wysyłanych na parafije 1872-1885"10, „Akta Konsystorza Jeneralnego Dyecezyi Sandomierskiej Kościoła Wniebowzięcia NMP w Opatowie 1865-1983”"11, „Akta kościoła św. Katarzyny w Radomiu 1865-1936”" , „Akta sekularyzacyi zakonników 1835-1869"'13. Pojedyncze akta znajdują się w innych archiwach. Pomocne są również urzędowe spisy duchowieństwa (schematyzmy diecezjalne i zakonne) oraz prasa, zwłaszcza „Przegląd Katolicki”.

\section{Klasztor Bernardynów w Paradyżu}

W chwili kasaty do klasztoru należało 11 zakonników ${ }^{14}$. Byli to ojcowie: Edmund Mordziński - gwardian, Arseniusz Kawczyński - wikary, Józef Lubecki, Roman Kisielewski, Kandyd Stec, Filemon Kucharski i Bronisław Chaciński oraz bracia Andrzej Chmielewski, Brunon Motylewski, Sergiusz Kroczewski i Eliasz Brylski ${ }^{15}$. Faktycznie w klasztorze przebywało jednak 8 zakonników, gdyż o. Kandyd Stec zastępował czasowo proboszcza w Skaryszewie, o. Filemon Kucharski w podobnym charakterze przebywał w Żeleźnicy, a br. Eliasz Brylski przebywał w więzieniu jako podejrzany o udział w powstaniu styczniowym ${ }^{16}$.

Już 29 listopada 1864 r. przybyli zakonnicy z Radomia, pierwsze ofiary kasaty. Byli to: ojcowie Benedykt Piotrowski i Antoni Komendecki oraz bracia zakonni Remigiusz Starachowski, Jakub Stąporkiewicz i Cyprian Kotowicz. Dzień później dotarli zakonnicy z Kazanowa: ojcowie Kazimierz Porowski, Damian Drożdżal i Gliceriusz Chybowski oraz brat zakonny Hermenegild Potkański. Tego samego dnia dojechali zakonnicy z Karczówki koło Kielc: ojcowie Sylwester

${ }^{6}$ Dalej: ArSd, BernPar 1865-1877.

${ }^{7}$ Dalej: ArSd, BernPar 1871-1902.

${ }^{8}$ Dalej: ArSd, RefWK 1864-1878. W tym wypadku tytuł poszytu i data początkowa są mylące. W poszycie są zarówno dokumenty dotyczące dominikanów, jak i reformatów.

${ }^{9}$ Dalej: ArSd, RefWK 1870-1893.

${ }^{10}$ Dalej: ArSd, ZakPar 1872-1885.

${ }^{11}$ Dalej: ArSd, BernOp 1865-1983.

${ }^{12}$ Dalej: ArSd, BernRad 1865-1936.

${ }^{13}$ Dalej: ArSd, Sekul. 1835-1869.

${ }^{14}$ Obszerniej o pokasacyjnych dziejach tego klasztoru zob. R. Prejs, Klasztor bernardynów w Paradyżu (Wielkiej Woli) w latach 1864-1893. Przykład funkcjonowania klasztoru etatowego w Królestwie Polskim w warunkach pokasacyjnych, „Studia Franciszkańskie”, 11 (2001) s. 275-305.

${ }^{15}$ Schem. Sandom. 1864, s. 78; Schematismus Patrum et Fratrum necnon Monialium Ordinis Minorum S.P.N. Francisci regularis observantiae vulgo Bernardinorum Provinciae Minoris Poloniae pro anno Domini 1863, [Warszawa 1863], s. 56 (Rzadki druk; korzystałem z egzemplarza w Bibliotece Metropolitalnego Seminarium Duchownego w Warszawie).

${ }^{16} \mathrm{ArSd}$, BernPar 1865-1877, protokół wizytacji klasztoru z 5 X 1865. 
Grzybowski, Martynian Maszewski i Wiktoryn Sikorski oraz bracia zakonni Spirydion Stangierski i Pacyfik Juszko. Dnia 30 listopada 1864 r. dotarli też zakonnicy z Opatowa: ojcowie Aleksy Zienkiewicz i Anastazy Gilewicz, klerycy Grzegorz Łukasik i Bernardyn Iżyłowski oraz bracia zakonni Izaak Kossakiewicz i Hygin Komorowski ${ }^{17}$. Obecność wymienionych kleryków była wynikiem pomyłki: obaj należeli do klasztoru w Lublinie, a w dniu kasaty przebywali w Opatowie celem przyjęcia święceń. Gdyby ściśle interpretować ukaz kasacyjny, obaj winni być dołączeni do pozostałych zakonników z Lublina, którzy zostali wywiezieni do klasztoru w Kazimierzu Biskupim. Nie wiadomo, czy nie dość jasno przedstawili oficerowi kierującemu wykonaniem kasaty, że są z innego klasztoru, czy ten nie przejął się ich wyjaśnieniami, dość, że znaleźli się w Paradyżu. W wyniku przybycia wspomnianych zakonników w Paradyżu znalazło się łącznie 17 kapłanów, 2 kleryków i 12 braci zakonnych, razem 31 zakonników.

Obecność tak dużej grupy zakonników narzucała konieczność znalezienia im stosownego zajęcia i utrzymania. Tradycyjnym u bernardynów zajęciem duszpasterskim była pomoc kapłanom diecezjalnym w duszpasterstwie parafialnym. Już w grudniu 1864 r. wyjechali do pomocy w parafiach: o. Gliceriusz Chybowski do Końskich, o. Bronisław Chaciński do Radoszyc, o. Martynian Maszewski do Wzdołu i o. Benedykt Piotrowski do Kowali-Stępociny ${ }^{18}$. Kleryk Grzegorz Łukasik udał się natomiast do Lublina celem starań o przyjęcie do tamtejszego seminarium duchownego ${ }^{19}$. W styczniu 1865 r. o. Wiktoryn Sikorski udał się z pomocą duszpasterską do Chęcin (diec. krakowsko-kielecka) ${ }^{20}$. Opuścili zakon bracia Pacyfik Juszko i Hygin Komorowski, którzy prawdopodobnie nie mieli złożonych ślubów zakonnych ${ }^{21}$. Przybył natomiast 15 czerwca 1865 r. dotychczasowy prowincjał Joachim Nizner, ale nic nie wskazuje, by próbował wykonywać swą jurysdykcję, a przeciwnie: w warunkach pokasacyjnych uznał się za zwolnionego z funkcji zwierzchnika prowincji zakonnej ${ }^{22}$.

Powiększenie stanu personalnego nastąpiło 6 października 1865 r., gdy przybyli zakonnicy ze skasowanego klasztoru w Łukowie: o. Hipolit Kaszuba, kleryk Faustyn Kamiński i br. Stefan Matuszak, a ze skasowanego klasztoru w Krześlinie przyjechał o. Rajmund Górzyński. Po kilkunastu dniach, 16 października 1865 r. dołączył do grupy o. Cherubin Lisiewicz, dotychczas przebywający w areszcie z powodu udziału w powstaniu styczniowym. Do klasztoru w Łukowie należał też

${ }^{17}$ ArSd, BernPar 1865-1877, Lista osób zakonnych Zgromadzenia Ks.Ks. Bernardynów Klasztoru Wielko-Wolskiego [29 VIII 1866].

${ }^{18}$ ArSd, BernPar 1865-1877, protokół wizytacji klasztoru w Paradyżu 5 X 1865, uwagi wizytatora klasztorów z 22 VII 1867.

${ }^{19}$ ArSd, BernPar 1865-1877, protokoły wizytacji klasztoru w Paradyżu 5 X 1865 i 31 VIII 1866, uwagi wizytatora klasztorów z 22 VII 1867.

${ }^{20}$ ArSd, Sekul. 1835-1869, bp kielecki 15 III 1866 do bpa sandomierskiego.

${ }^{21}$ ArSd, BernPar 1865-1877, protokół wizytacji klasztoru w Paradyżu 5 X 1865.

${ }^{22}$ ArSd, BernPar 1865-1877, Lista osób zakonnych Zgromadzenia Ks.Ks. Bernardynów Klasztoru Wielko-Wolskiego [niedat., po 6 X 1865], Lista osób zakonnych znajdujących się w Klasztorze XX. Bernardynów w Wielkiej Woli sporządzona dnia 18 Stycznia 1866 r., protokół wizytacji klasztoru 5 X 1865. 
o. Piotr Zbrożek, ale on dotarł do Paradyża dopiero 11 grudnia 1865 r. $^{23}$ Dnia 19 grudnia 1865 r. po opuszczeniu więzienia wrócił do Paradyża inny uczestnik powstania styczniowego, br. Eliasz Brylski²4. Dnia 27 czerwca 1866 r. znalazł się w Paradyżu o. Józafat Piotrowski, który dotychczas pomagał w pracy duszpasterskiej w różnych parafiach diecezji sandomierskiej; podobna była sytuacja o. Letusa Śniegockiego, który dotarł do klasztoru 3 sierpnia $1866 \mathrm{r}^{25} \mathrm{~W}$ tym też czasie zamieszkał w Paradyżu o. Augustyn Czarnocki, dotychczasowy kapelan Bernardynek w Świętej Katarzynie, ale w obowiązkach kapelana zastąpił go o. Kazimierz Porowski, który z tego powodu opuścił klasztor w Paradyżu ${ }^{26}$. Ostatnia większa grupa zakonników przybyła do Paradyża w 1869 r. po skasowaniu klasztoru w Radecznicy. Dnia 10 lutego 1869 r. przyjechali o. Tytus Rycerz i o. Teodor Więckowski, a 11 lipca 1869 r. przybył o. Salwator Kaczorowski ${ }^{27}$.

W kolejnych latach zdarzały się pojedyncze wypadki przybycia jakiegoś zakonnika do Paradyża: 2 stycznia 1871 r. przybył o. Emil Sniegocki ${ }^{28}, 5$ stycznia 1871 r. dotarł o. Mikołaj Mikołajewski, a 10 stycznia 1871 r. o. Marcin Przypkowski $^{29}$. Dnia 8 czerwca 1879 r. do klasztoru w Paradyżu został przeniesiony o. Piotr Kowalski $^{30}$, wreszcie 10 października 1885 r. znalazł się w Paradyżu o. Erazm Czachorowski, dotychczasowy rektor kościoła pobernardyńskiego w Tykocinie ${ }^{31}$. Szczególnym przypadkiem było przybycie do Paradyża Franciszkanina konwen-

${ }^{23}$ ArSd, BernPar 1865-1877, Komisja Rządowa Spraw Wewnętrznych i Duchownych 25 X/6 XI 1865 do bpa sandomierskiego, Lista osób zakonnych Zgromadzenia Ks.Ks. Bernardynów Klasztoru Wielko-Wolskiego [niedat., po 6 X 1865], Lista osób zakonnych znajdujących się w Klasztorze XX. Bernardynów w Wielkiej Woli sporządzona dnia 18 Stycznia 1866 r. Łamane daty oznaczają, że dokument jest datowany według starego i nowego stylu (kalendarza juliańskiego i gregoriańskiego).

${ }^{24}$ ArSd, BernPar 1865-1877, Lista osób zakonnych Zgromadzenia Ks.Ks. Bernardynów Klasztoru Wielko-Wolskiego [niedat., po 6 X 1865], Lista osób zakonnych znajdujących się w Klasztorze XX. Bernardynów w Wielkiej Woli sporządzona dnia 18 Stycznia 1866 r., przełożony klasztoru 22 I 1866 i 11 IV 1866 do wizytatora klasztorów.

${ }^{25}$ ArSd, BernPar 1865-1877, konsystorz sandomierski 26 IV 1866 i 9 VII 1866 do wizytatora klasztorów, uwagi wizytatora klasztorów z 22 VII 1867.

${ }^{26}$ ArSd, BernPar 1865-1877, Lista osób zakonnych Zgromadzenia Ks.Ks. Bernardynów Klasztoru Wielko-Wolskiego [niedat., po 6 X 1865], Lista osób zakonnych znajdujących się w Klasztorze XX. Bernardynów w Wielkiej Woli sporządzona dnia 18 Stycznia 1866 r., Lista osób zakonnych Zgromadzenia Ks.Ks. Bernardynów Klasztoru Wielko-Wolskiego [29 VIII 1866].

${ }^{27}$ ArLb, sygn. 60 IVb 191, k. 180-182, 195; R. Prejs, Klasztor bernardynów w Radecznicy w latach 1864-1919, w: Na tym miejscu chwała Boga Najwyższego odprawiać się będzie... W setna rocznice rewindykacji klasztoru oo. Bernardynów w Radecznicy (1919-2019), red. I. M. Janusz, A. K. Sitnik, Kalwaria Zebrzydowska 2019, s. 126-129.

${ }^{28}$ ArSd, BernPar 1871-1902, przełożony klasztoru 23 XII 1870/4 I 1871 do konsystorza sandomierskiego, przełożony klasztoru reformatów w Wysokim Kole 2 I 1871 do konsystorza sandomierskiego.

${ }^{29}$ ArSd, BernPar 1871-1902, przełożony klasztoru 26 XII 1870/7 I 1871 i 11 I 1871 do konsystorza sandomierskiego.

${ }^{30}$ ArSd, BernPar 1871-1902, przełożony klasztoru 29 V/10 VI 1879 do konsystorza sandomierskiego.

${ }^{31}$ ArSd, BernPar 1871-1902, generał-gubernator warszawski 31 VIII 1885 do bpa sandomierskiego, przełożony klasztoru 10 X 1885 do konsystorza sandomierskiego. 
tualnego o. Władysława Włodarczyka, który dotychczas był kapelanem Klarysek w Chęcinach, ale postępująca choroba oczu uniemożliwiała mu samodzielne pełnienie obowiązków duszpasterskich i to było powodem umieszczenia go w klasztorze $^{32}$. Dlaczego udał się do Paradyża, a nie do któregoś z klasztorów na terenie diecezji kieleckiej, w której leżały Chęciny - trudno odpowiedzieć.

Przybycia zakonników powiększały stan personalny tylko w pierwszym okresie po kasacie. Potem nie przewyższały ubytków. Te zaś następowały szybko. Wspomniani wyżej zakonnicy, którzy udali się z pomocą duszpasterską do różnych parafii, już nie powrócili do klasztoru, a niemal wszyscy starali się o sekularyzację. $\mathrm{O}$ ich dalszych losach wspomniano niżej. $\mathrm{W}$ tym miejscu wymieniono tylko zakonników opuszczających klasztor, by przejść do pracy parafialnej: w 1866 r. był to o. Joachim Nizner, w 1867 r. o. Bronisław Chaciński i o. Augustyn Czarnocki, w 1868 r. o. PiotrZbrożek, w 1870r. o. TeodorWięckowski, w 1871 r. o. Jozafat Piotrowski, w 1873 r. o. Edmund Mordziński, w 1874 r. o. Rajmund Górzyński.

Jeszcze w 1866 r. odeszli z zakonu bracia zakonni Eliasz Brylski i Hermenegild Potkański ${ }^{33}$. Obaj nie mieli złożonych ślubów zakonnych. Inny był charakter odejścia z Paradyża ojców Emila Śniegockiego i Piotra Kowalskiego. Pierwszy, człowiek wątpliwej reputacji moralnej, w marcu 1873 r. przeszedł na protestantyzm ${ }^{34}$. Drugi w 1892 r. wyraził zamiar wyjazdu do Ameryki. Otrzymawszy stosowne pozwolenia władz państwowych, opuścił klasztor 3 listopada 1892 r. Dalsze jego dzieje nie są znane, nie wiadomo, czy w ogóle dotarł na drugą półkulę 35 .

Ubytki personalne przede wszystkim były jednak spowodowane zgonami. Kolejno umierali: 16 stycznia 1867 r. br. Andrzej Chmielewski, 5 lutego 1868 r. o. Damian Drożdżal, 12 maja 1868 r. o. Remigiusz Kaznowski, 7 sierpnia 1872 r. br. Brunon Motylewski, 21 czerwca 1873 r. o. Atanazy Gilewicz, 1 stycznia 1875 r. o. Cherubin Lisiewicz, 18 marca 1876 r. br. Remigiusz Starachowski, 7 stycznia 1877 r. o. Sylwester Grzybowski, 22 stycznia 1883 r. br. Stefan Matuszak, 25 października 1884 r. o. Hipolit Kaszuba, 29 stycznia 1885 r. o. Antoni Komendecki, 4 marca 1886 r. o. Letus Śniegocki, 4 września 1886 r. o. Marcin Przypkowski, 16 lipca 1887 r. o. Henryk Kierszulis, 2 marca 1888 r. o. Erazm

${ }^{32}$ ArSd, BernPar 1871-1902, generał-gubernator warszawski 31 VIII 1885 do bpa sandomierskiego, przełożony klasztoru 10 X 1885 do konsystorza sandomierskiego.

${ }^{33}$ ArSd, BerPar 1865-1877, przełożony klasztoru 11 IV 1866 do wizytatora klasztorów.

${ }^{34}$ ArSd, BernPar 1871-1902, przełożony klasztoru 23 XII 1870/4 I 1871 do konsystorza sandomierskiego, przełożony klasztoru 15/27 IX 1871 do bpa sandomierskiego, przełożony klasztoru 27 IV 1872 do wizytatora klasztorów, przełożony klasztoru 18 II/2 III 1873 do konsystorza sandomierskiego, wizytator klasztorów 23 II/7 III 1873 do bpa sandomierskiego.

${ }^{35}$ ArSd, BernPar 1871-1902, przełożony klasztoru 21 VII 1891 do konsystorza sandomierskiego, Kowalski 28 VII 1891 do konsystorza sandomierskiego, wizytator klasztorów 2/14 VII 1892 (notatka służbowa), konsystorz sandomierski 24 IX/6 X 1892 do przełożonego klasztoru, przełożony klasztoru 26 X/7 XI 1892 do konsystorza sandomierskiego. Popularne imię i nazwisko nie pozwala na jednoznaczną identyfikację osoby wśród duchowieństwa polskiego w Stanach Zjednoczonych. 
Czachorowski, 16 maja 1893 r. o. Mikołaj Mikołajewski, 27 maja 1893 r. br. Cyprian Kotowicz ${ }^{36}$.

Do ubytków należy też wliczyć wyjazd 10 stycznia 1889 r. o. Tytusa Rycerza na kapelana Bernardynek w Świętej Katarzynie. Zakonnik nie powrócił już do Paradyża - zmarł w Swiętej Katarzynie 19 marca 1903 r. ${ }^{37}$

Zmiany personalne w klasztorze bernardynów w Paradyżu przedstawiono w poniższej tabeli.

Tabela 1. Liczba zakonników w klasztorze Bernardynów w Paradyżu [1865-1893]

\begin{tabular}{|c|c|c|c|c|}
\hline Rok & Kaplani & Klerycy & Bracia & Razem \\
\hline 1865 & 17 & 2 & 12 & 31 \\
\hline 1866 & 13 & 3 & 11 & 27 \\
\hline 1869 & 11 & 1 & 7 & 19 \\
\hline 1870 & 13 & - & 7 & 20 \\
\hline 1871 & 13 & - & 7 & 20 \\
\hline 1872 & 17 & - & 7 & 24 \\
\hline 1873 & 15 & - & 6 & 21 \\
\hline 1874 & 13 & - & 6 & 19 \\
\hline 1875 & 13 & - & 6 & 19 \\
\hline 1876 & 11 & - & 6 & 17 \\
\hline 1877 & 11 & - & 5 & 16 \\
\hline 1878 & 9 & - & 5 & 14 \\
\hline 1879 & 9 & - & 5 & 14 \\
\hline 1880 & 10 & - & 5 & 15 \\
\hline 1881 & 10 & - & 5 & 15 \\
\hline 1882 & 10 & - & 5 & 15 \\
\hline 1884 & 10 & - & 4 & 14 \\
\hline 1885 & 9 & - & 4 & 13 \\
\hline 1886 & 9 & - & 4 & 13 \\
\hline 1887 & 7 & - & 4 & 11 \\
\hline 1888 & 6 & - & 4 & 10 \\
\hline 1889 & 4 & - & 4 & 8 \\
\hline 1890 & 4 & - & 4 & 8 \\
\hline 1891 & 5 & - & 4 & 9 \\
\hline 1892 & 4 & - & 4 & 8 \\
\hline 1893 & 4 & - & 4 & 8 \\
\hline
\end{tabular}

Źródło: Schem. Sandom. 1869-1893, passim.

${ }^{36}$ Daty zgonu za: Schem. Sandom. 1869-1894, passim.

${ }^{37}$ Schem. Sandom. 1904, s. 93. 
Decyzja o zamknięciu klasztoru w Paradyżu zapadła w 1893 r., choć nie jest znana dokładna daty jej powzięcia. Generał-gubernator warszawski pismem z 8 sierpnia 1893 r. powiadomił biskupa sandomierskiego, że kasata klasztoru jest zdecydowana i wyznaczył jej wykonanie na 18 września 1893 r. Władze kościelne zleciły asystowanie przy zamknięciu klasztoru dziekanowi opoczyńskiemu i proboszczowi w Wąchocku, ks. Piotrowi Górskiemu ${ }^{38}$. Obecność dziekana przy kasacie może razić, ale była konieczna: miał dopilnować, by nie doszło do profanacji Najświętszego Sakramentu, zabezpieczyć relikwie, sprzęty kościelne, naczynia i szaty liturgiczne. Miał też czuwać, aby w trakcie likwidacji klasztoru nic nie zginęło z rzeczy kościelnych. Czterech zakonników: o. Aleksy Zienkiewicz, o. Salwator Kaczorowski, br. Spirydion Stangierski i br. Jakub Stąporkiewicz, zostało wywiezionych do klasztoru bernardynów w Kole - ostatniego klasztoru bernardynów w dawnym Królestwie Polskim ${ }^{39}$. Br. Sergiusz Kroczewski, do którego już od dłuższego czasu istniały poważne zastrzeżenia moralne, został przy okazji kasaty wydalony z zakonu ${ }^{40}$. Kościołem poklasztornym opiekował się początkowo ks. Tomasz Jachimowicz jako rektor, a 2 maja 1896 r. przy kościele została utworzona filia duszpasterska, przekształcona w $1918 \mathrm{r}$. w pełnoprawną parafię ${ }^{41}$.

\section{Klasztor Reformatów w Wysokim Kole}

Klasztor w Wysokim Kole był klasztorem dominikanów. Ukazem kasacyjnym z 1864 r. został uznany za klasztor etatowy. W 1870 r. władze carskie usunęły dominikanów z zajmowanego budynku i wywiozły ich do klasztoru w Lublinie, a w Wysokim Kole osadziły reformatów z Jędrzejowa. Powody tego posunięcia nie są znane. Nie zmniejszyła się liczba dominikanów czy reformatów poniżej wymagań ukazu kasacyjnego, nie zachodziło też połączenie dwóch dotychczasowych klasztorów etatowych w jeden, skoro dominikanie i reformaci to różne zakony. Jedynym wytłumaczeniem zaistniałego faktu może być represja, ale trudno wyjaśnić, z jakiego powodu została zastosowana ${ }^{42}$.

W 1870 r. z Jędrzejowa przybyło 13 zakonników: ojcowie Krescenty Bielawski, Anzelm Dziedziszewski, Kamil Skubik, Paweł Stopiński, Leopold Wilko-

${ }^{38}$ ArSd, BernPar 1871-1902, generał-gubernator 8 VIII 1893 do bpa sandomierskiego, konsystorz sandomierski 18/30 VIII 1893 do ks. Górskiego.

${ }^{39}$ ArSd, BernPar 1871-1902, raport ks. Piotra Górskiego z 8/20 IX 1893 o przebiegu kasaty.

${ }^{40}$ ArSd, BernPar 1865-1877, Lista osób zakonnych Zgromadzenia Ks.Ks. Bernardynów Klasztoru Wielko-Wolskiego [29 VIII 1866], notatki wizytatora klasztorów z wizytacji 22 VII 1867; BernPar 1871-1902, przełożony klasztoru 16 V 1892 do wizytatora klasztorów.

${ }^{41}$ J. Wiśniewski, Dekanat opoczyński, Radom 1913, s. 306; A. Pabin, Paradyż, w: Klasztory bernardyńskie, s. 254. Zob. też: R. Prejs, Bernardyni prowincji małopolskiej po kasacie 1864 r., „Studia Franciszkańskie”, 10 (1999) s. 327-372; tenże, Bernardyni w Królestwie Polskim po kasacie 1864 r., w: Pięćset pięćdziesiąt lat obecności oo. Bernardynów w Polsce (1453-2003), red. W.F. Murawiec, D.A. Muskus, Kalwaria Zebrzydowska 2006, s. 427-513; tenże, Stownik biograficzny zakonników franciszkańskich Królestwa Polskiego po kasacie 1864 r., Poznań 2004; tenże, Zakonnicy franciszkańscy Królestwa Polskiego po kasacie 1864 roku. Dzieje - postawy, Warszawa 2003.

${ }^{42}$ ArKi, sygn. OK 20/7, k. 249-251v; ArSd, RefWK 1870-1893, Lista zakonników klasztoru Reformatów w Wysokim Kole przybyłych z klasztoru w Jędrzejowie, sporządzona 6/18 X 1870. 
wicz, Ludwik Kaszewski, Kornel Zakrzewski, Walerian Olszewski, Ignacy Bisikiewicz, Mikołaj Kalinowski, Sylwester Krombach i Emil Śniegocki oraz brat zakonny Wincenty Cichocki ${ }^{43}$. Emil Śniegocki był bernardynem; w klasztorze w Jędrzejowie przebywał na pokucie, a wkrótce został przeniesiony do Paradyża, o czym wspomniano wyżej.

Większa grupa zakonników przyjechała do Wysokiego Koła w 1874 r. po skasowaniu klasztoru w Smolanach (diecezja sejneńska). Dotarli wówczas: o. Tymoteusz Budziszewski, o. Chryzostom Dąbkowski, o. Gerard Kamiński, o. Józef Stankiewicz i o. Joachim Wierzbiłło oraz br. Jakub Łopiński i br. Seweryn Piórkowski. Jako ciekawostkę warto dodać, że nie dojechali wszyscy jednego dnia: korzystając z okazji, niektórzy po drodze odwiedzili krewnych lub znajomych, stąd przyjazdy rozciągnęły się na styczeń i luty ${ }^{44}$.

Na mocy decyzji władz państwowych 27 lipca 1879 r. został przeniesiony z klasztoru w Kaliszu do Wysokiego Koła br. Jakub Herkt. Nie wiadomo, co było powodem translokaty. W źródłach występuje do 1882 r., dalszych dziejów nie udało się ustalićc ${ }^{5}$.

Dnia 28 lipca 1882 r. przybył z zesłania w Rosji o. Zygmunt Grzybowski. Mimo że miał pozwolenie władz państwowych na powrót do Królestwa Polskiego, te rychło zabroniły mu mieszkania w klasztorze. Dnia 16 września $1882 \mathrm{r}$. musiał opuścić Wysokie Koło i jako rezydent osiadł w niedalekim Sieciechowie. Zmarł w szpitalu w Kozienicach 19 września 1884 r. ${ }^{46}$

Bardziej skomplikowane były dzieje o. Filipa Gulczyńskiego. Kasata zastała go, gdy był klerykiem w klasztorze w Warszawie. W 1868 r. zgłosił się do seminarium duchownego w Sandomierzu. Jeszcze tego samego roku otrzymał święcenia kapłańskie i został wikariuszem katedry w Sandomierzu. W 1869 r. przeszedł na wikariat do Końskich, a w 1872 r. do Białaczowa. Formalnie pozostawał zakonnikiem i nic nie wiadomo, by zabiegał o sekularyzację. Ale okazało się, że młody kapłan ma problemy z nadużywaniem alkoholu. W tej sytuacji 2/14 maja 1876 r. został skierowany do klasztoru w Wysokim Kole, a w konwencie poprawił się o tyle, że nie dawał publicznego zgorszenia. Zmarł w Wysokim Kole 15 listopada $1881 \mathrm{r}^{47}$

Podobnie jak z Paradyża, również i z Wysokiego Koła zakonnicy odchodzili, by osiąść w innych miejscach. Dwóch zakonników przeszło do klasztoru reforma-

\footnotetext{
${ }^{43}$ ArSd, RefWK 1870-1893, Lista zakonników klasztoru Reformatów w Wysokim Kole przybyłych z klasztoru w Jędrzejowie, sporządzona 6/18 X 1870.

${ }^{44}$ ArSd, RefWK 1864-1878, przełożony klasztoru 6/18 II 1874 do wizytatora klasztorów.

${ }^{45}$ ArSd, RefWK 1870-1893, przełożony klasztoru 16/28 VII 1879 do konsystorza; Schem. Sandom. 1880-1883, passim.

${ }^{46}$ ArSd, RefWK 1870-1893, przełożony klasztoru 17/29 VII 1882 do wizytatora klasztorów, wizytator klasztorów 4/16 IX 1882 do biskupa: Schem. Sandom. 1883-1885, passim.

${ }^{47}$ ArSd, RefWK 1864-1878, przełożony klasztoru 11/23 XII 1876 do wizytatora klasztorów; ArSd, RefWK 1870-1893, przełożony klasztoru 2/14 V 1876 i 8 III 1877 do konsystorza, wizytator klasztorów 17/29 XI 1881 do administratora diecezji; Schem. Sandom. 1869-1883, passim.
} 
tów we Włocławku: o. Tymoteusz Budziszewski w 1876 r. ${ }^{48}$, a o. Gerard Kamiński w 1885 r. ${ }^{49}$ Częściej jednak kierunkiem była praca parafialna. O. Walerian Olszewski 25 maja 1871 r. udał się do diecezji lubelskiej ${ }^{50}$, o. Mikołaj Kalinowski 14 czerwca 1872 r. wyjechał do archidiecezji warszawskiej ${ }^{51}$, o. Sylwester Krombach w 1875 r. podjął pracę w diecezji lubelskiej ${ }^{52}$, o. Joachim Wierzbiłło 8 maja 1876 r. udał się do archidiecezji warszawskiej ${ }^{53}$, a o. Ignacy Bisikiewicz w $1881 \mathrm{r}$. podjął pracę parafialną w diecezji sandomierskiej ${ }^{54}$. Br. Jakub Łopieński otrzymał od władz państwowych tzw. uwolnienie od życia zakonnego i 13 grudnia $1875 \mathrm{r}$. opuścił klasztor ${ }^{55}$.

Wspólnotę zakonną w Wysokim Kole dotykały też liczne zgony. Kolejno zmarli: o. Leopold Wilkowicz 20 sierpnia 1871 r., o. Anzelm Dziedziszewski 15 lutego 1872 r., o. Kamil Skubik 11 marca 1873 r., o. Paweł Stopiński 13 marca 1873 r., o. Ludwik Kaszewski 15 maja 1873 r., o. Chryzostom Dąbkowski 19 czerwca 1875 r., o. Kornel Zakrzewski 24 grudnia 1879 r., br. Seweryn Piórkowski 19 maja 1880 r., br. Wincenty Cichocki 8 czerwca 1882 r., o. Krescenty Bielawski 29 czerwca 1886 r. i o. Józef Stankiewicz 17 sierpnia 1891 r. $^{56}$

Tabela 2. Liczba zakonników w klasztorze Reformatów w Wysokim Kole [1870-1891]

\begin{tabular}{|c|c|c|c|}
\hline Rok & Kaplani & Bracia & Razem \\
\hline $\mathbf{1}$ & $\mathbf{2}$ & $\mathbf{3}$ & $\mathbf{4}$ \\
\hline 1870 & 12 & 1 & 13 \\
\hline 1871 & 12 & 1 & 13 \\
\hline 1872 & 9 & 1 & 10 \\
\hline
\end{tabular}

${ }^{48}$ ArSD, RefWK 1870-1893, przełożony klasztoru 9/28 II 1874 do wizytatora klasztorów, Budziszewski 12 VII 1875 do biskupa, przełożony klasztoru 24 XII 1875/5 I 1876 do wizytatora klasztorów.

${ }^{49}$ ArSd, RefWK 1864-1878, Kamiński 8 IV 1874, 4 VII 1874 i 24 IX 1874 do wizytatora klasztorów, Kamiński 21 VIII/2 IX 1878 do biskupa; Archiwum Diecezjalne we Włocławku (dalej: ArWł), sygn. KGK V 23, k. 277.

${ }^{50} \mathrm{ArSd}$, RefWK 1864-1878, przełożony klasztoru 3/15 VI 1871 do wizytatora klasztorów.

${ }^{51}$ ArSD, RefWK 1870-1893, Kalinowski 15/27 IV 1871 i 26 V/7 VI 1871 do bpa sandomierskiego, ukaz Kolegium Duchownego w Petersburgu z 3 IV 1872, wizytator klasztorów 5 VII 1872 do konsystorza sandomierskiego.

${ }^{52}$ ArSD, RefWK 1870-1893, wizytator klasztorów 24 III/5 IV 1875 do bpa sandomierskiego, generał-gubernator warszawski 28 VI/10 VII 1875 do bpa sandomierskiego, przełożony klasztoru 29 VII/5 VIII 1875 do konsystorza sandomierskiego.

${ }^{53}$ ArSD, RefWK 1870-1893, administrator archidiecezji warszawskiej 13/25 XI 1875 do bpa sandomierskiego, generał-gubernator warszawski 27 III 1876 do bpa sandomierskiego, przełożony klasztoru 29 IV/11 V 1876 do konsystorza sandomierskiego.

${ }^{54}$ „Przegląd Katolicki”, 19 (1881) s. 530.

${ }^{55}$ ArSd, RefWK 1864-1878, Łopieński 5/17 VIII 1874 do wizytatora klasztorów; ArSd RefWK 1870-1893, wizytator klasztorów 3/15 VII 1875 do biskupa, protokół z 2/14 VII 1875, Łopieński 3/15 VII 1875 do biskupa, Łopieński 6/18 I 1875 i 1 II 1875 do wizytatora klasztorów.

${ }^{56}$ Daty zgonów za: Schem. Sandom. 1872-1892, passim. 


\begin{tabular}{|c|l|l|l|}
\hline $\mathbf{1}$ & $\mathbf{2}$ & $\mathbf{3}$ & $\mathbf{4}$ \\
\hline 1873 & 7 & 1 & 8 \\
\hline 1874 & 4 & 1 & 5 \\
\hline 1875 & 8 & 3 & 11 \\
\hline 1876 & 6 & 2 & 8 \\
\hline 1877 & 6 & 2 & 8 \\
\hline 1878 & 6 & 2 & 8 \\
\hline 1879 & 6 & 2 & 7 \\
\hline 1880 & 5 & 2 & 7 \\
\hline 1881 & 5 & 2 & 5 \\
\hline 1882 & 3 & 2 & 3 \\
\hline 1883 & 3 & 1 & 3 \\
\hline 1884 & 3 & - & 2 \\
\hline 1885 & 3 & - & 1 \\
\hline 1886 & 2 & - & 1 \\
\hline 1887 & 1 & - & 1 \\
\hline 1888 & 1 & - & 1 \\
\hline 1889 & 1 & - & 1 \\
\hline 1890 & 1 & - & 7 \\
\hline 1891 & 1 & - & 7 \\
\hline
\end{tabular}

Źródło: Schem. Sandom. 1871-1891, passim.

Formalnej kasaty klasztoru w Wysokim Kole nigdy nie dokonano. Prawdopodobnie władze carskie uważały, że z chwilą śmierci ostatniego zakonnika klasztor przestał istnieć i nie ma potrzeby podejmowania formalnych decyzji. Ostatnim zgonem była wspomniana wyżej śmierć o. Józefa Stankiewicza. Kościół poklasztorny został od 1892 r. siedzibą parafii w Regowie, która od tego czasu przyjęła nazwę parafia w Wysokim Kole ${ }^{57}$.

\section{Rektorzy kościołów poklasztornych; kapelani}

W myśl przepisów ukazu kasacyjnego przy kościołach likwidowanych klasztorów należało pozostawić jednego lub dwóch zakonników celem zapewnienia ciągłości w odprawianiu nabożeństw. Ponadto w trakcie przeprowadzania akcji kasacyjnej okazało się, że w niektórych klasztorach przebywają zakonnicy tak starzy lub schorowani, że byli niezdolni do podróży. Ich także pozostawiono w dotychczasowych konwentach. W praktyce zatem klasztor, w którym pozostawiono dwóch zakonników do obsługi kościoła i jednego schorowanego, funkcjonował nadal, choć oczywiście o bardzo zmniejszonej obsadzie, a w świadomości ludzi

\footnotetext{
${ }^{57}$ „Przegląd Katolicki”, 37 (1899) s. 395-397.
} 
ciągle istniał, zwłaszcza jeśli pozostawiony zakonnik starał się nadal - w miarę możności - podtrzymywać dawne nabożeństwa i odpusty ${ }^{58}$.

$\mathrm{Na}$ terenie diecezji sandomierskiej rektorami kościołów poklasztornych zostali: przy kościele pobernardyńskim w Kazanowie o. Wenanty Jasiewicz ${ }^{59}$, przy kościele pobernardyńskim w Opatowie o. Henryk Kierszulis ${ }^{60}$, przy kościele pobernardyńskim w Radomiu o. Teofil Trojanowski i o. Rogeriusz Kaznow$\mathrm{ski}^{61}$, a dodatkowo pozostał br. Czesław Wolski ${ }^{62}$, przy kościele pofranciszkańskim w Smardzewicach o. Ambroży Boiński ${ }^{63}$, przy kościele pofranciszkańskim w Zawichoście o. Serafin Pawłecki ${ }^{64}$, przy kościele poreformackim w Rytwianach o. Amarantus Józefowski ${ }^{65}$, przy kościele poreformackim w Sandomierzu o. Cyriak Sobczyński ${ }^{66}$, przy kościele poreformackim w Solcu o. Filip Jóźwik ${ }^{67}$.

Już w marcu 1865 r. z rektoratu kościoła pobernardyńskiego w Radomiu został odwołany o. Rogeriusz Kaznowski. Dziekan radomski we wniosku do biskupa o odwołanie zakonnika napisał, że o. Rogeriusz ulega pijaństwu. Zmiana rektora nastapiła 19 marca 1865 r., a następcą o. Rogeriusza został o. Arseniusz Kawczyński, przybyły z klasztoru w Paradyżu. O. Rogeriusz udał się na jego miejsce do Paradyża ${ }^{68}$. Nie ma jednak śladów, by w przyszłości potwierdzało się jego uzależnienie od alkoholu. Czyżby zarzut dziekana był sformułowany na wyrost? W maju 1865 r. zaistniała potrzeba zmiany rektora w Opatowie. O. Henryk Kierszulis okazał się człowiekiem nieodpowiedzialnym i uzależnionym od alkoholu, a zarzuty były w tym wypadku prawdziwe, jak to pokazała przyszłość. Zo-

${ }^{58}$ Obszerniej na ten temat zob.: R. Prejs, Rektorzy kościołów pofranciszkańskich. Z dziejów zakonników Królestwa Polskiego po kasacie 1864 r., „Studia Franciszkańskie”, 9 (1998) s. 125-154.

${ }^{59}$ Schem. Sandom. 1869-1884, passim; Orzechowska, Własność, s. 202.

${ }^{60}$ ArSd, BernPar 1865-1877, Lista osób zakonnych Zgromadzenia Ks.Ks. Bernardynów Klasztoru Wielko-Wolskiego [29 VIII 1866]; ArSd, BernOp 1865-1983, Komisja Rządowa Spraw Wewnętrznych i Duchownych 30 IV/12 V 1865 do bpa sandomierskiego; Orzechowska, Własność, s. 202; K. Grudziński, Opatów, w: Klasztory bernardyńskie, s. 243.

${ }^{61}$ ArSd, BernPar 1865-1877, Lista osób zakonnych Zgromadzenia Ks.Ks. Bernardynów Klasztoru Wielko-Wolskiego [29 VIII 1866]; BernRad 1865-1936, dziekan radomski 30 XI 1864 do konsystorza sandomierskiego, proboszcz radomski 26 I 1865 do konsystorza sandomierskiego; Orzechowska, Własność, s. 202. Mylne wiadomości podaje K. Grudziński, Radom, w: Klasztory bernardyńskie, s. 299.

${ }^{62}$ ArSd, BernRad 1865-1936, dziekan radomski 30 XI 1864 do konsystorza sandomierskiego, spis majątku kościoła pobernardyńskiego w Radomiu 18 V 1865.

${ }^{63}$ ArWł, sygn. KGK V 17, k. 176, 393; Schem. Sandom. 1869-1873, passim; J. Wiśniewski, Dekanat opoczyński, Radom 1913, s. 218; E. Orzechowska, Własność, s. 202.

${ }^{64}$ Schem. Sandom. 1869-1871, passim; Orzechowska, Własność, s. 202.

${ }^{65}$ Schem. Sandom. 1869, s. 58; Orzechowska, Wtasność, s. 202.

${ }^{66}$ Schem. Sandom. 1869, s. 58; Orzechowska, Wtasność, s. 202; Z. Kalinowski, Kościót św. Józefa w Sandomierzu, cz. 2: Działalność duszpasterska reformatów sandomierskich i dzieje kościota od kasaty klasztoru w r. 1864, „Studia Sandomierskie”, 4 (1983-1984) s. 320-321.

${ }^{67}$ Schem. Sandom. 1869-1912, passim; „Kronika Diecezji Sandomierskiej”, 4 (1911) s. 243.

${ }^{68} \mathrm{ArSd}$, BernRad 1865-1936, proboszcz radomski 26 I 1865 do konsystorza sandomierskiego, dziekan radomski 8 II 1865 do konsystorza sandomierskiego. 
stał więc odesłany do klasztoru w Paradyżu, a na jego miejsce przybył z Paradyża o. Roman Kisielewski ${ }^{69}$.

W 1865 r. nastąpiły kolejne zmiany na rektorstwie kościoła pobernardyńskiego w Radomiu. Dnia 31 października 1865 r. zmarł o. Teofil Trojanowski, a niedługo później, 12 lutego 1866 r. - o. Arseniusz Kawczyński ${ }^{70}$. W międzyczasie opuścił zakon br. Czesław Wolski i na tym zakończyła się obecność bernardynów w Radomiu. Przy okazji należy poświęcić kilka zdań br. Wolskiemu. Nie był zakonnikiem po ślubach, lecz tzw. tercjarzem, zatem w świetle prawa kanonicznego mógł w każdej chwili swobodnie odejść do świata. W klasztorze był zakrystianem, a ponadto dość biegle znał się na konserwacji szat kościelnych. Po kasacie klasztoru dziekan radomski wnioskował do konsystorza, aby brata Czesława pozostawić przy kościele pobernardyńskim i wyjednać mu jakąś pensję u władz państwowych. Nic jednak nie wskazuje, by wniosek dziekana został uwzględniony ${ }^{71}$.

W 1872 r. nastąpiło usunięcie dotychczasowego rektora przy kościele pofranciszkańskim w Smardzewicach, o. Ambrożego Boińskiego. Nie wiadomo, co zarzucały mu władze państwowe: w powstanie styczniowe ani w żadną działalność patriotyczną się nie angażował, a przynajmniej nic o tym nie wiadomo, zarzutów moralnych także nie było pod jego adresem, tymczasem został usunięty z rektoratu na mocy decyzji namiestnika Królestwa Polskiego, a do klasztoru franciszkanów w Kaliszu, dokąd został przeznaczony, przybył 25 sierpnia 1872 r. eskortowany przez straż ziemską. Długo nie nacieszył się pobytem w Kaliszu: zmarł 10 stycznia $1873 \mathrm{r}^{72}$

Pozostali rektorzy pełnili swą funkcję do śmierci. W 1868 r. zmarli reformaci: 2 kwietnia 1868 r. rektor kościoła poklasztornego w Sandomierzu, o. Cyriak Sobczyński, a 26 lipca 1868 r. rektor w Rytwianach, o. Amarantus Józefowski. 27 stycznia 1870 r. zmarł rektor kościoła pofranciszkańskiego w Zawichoście, o. Serafin Pawłecki, a 12 marca 1876 r. zakończył życie o. Roman Kisielewski, rektor kościoła pobernardyńskiego w Opatowie. O. Wenanty Jasiewicz, rektor kościoła pobernardyńskiego w Kazanowie, zmarł 14 grudnia 1882 r. ${ }^{73}$ Ostatni z rektorów, reformat, o. Filip Jóźwik (niekiedy pisał się Juźwik), pozostawiony przy kościele poklasztornym w Solcu, w 1877 r. po pożarze kościoła poklasztornego przeszedł na wikariat w Solcu. W 1892 r. ponownie został rektorem kościoła poklasztornego i na tym stanowisku zmarł 25 lipca $1911 \mathrm{r}^{74} \mathrm{Z}$ jego śmiercią zakończyła się obecność rektorów kościołów pofranciszkańskich.

Kapelani sióstr zakonnych do pewnego stopnia pełnili podobną rolę jak rektorzy kościołów poklasztornych, przynajmniej w tym znaczeniu, że w kościołach

${ }^{69}$ ArSd, BernOp 1865-1983, Komisja Rządowa Spraw Wewnętrznych i Duchownych 30 IV/ 12 V 1865 do bpa sandomierskiego.

${ }^{70}$ ArSd, BernRad 1865-1936, proboszcz radomski 1/13 V 1870 do konsystorza sandomierskiego.

${ }^{71}$ ArSd, BernRad 1865-1936, dziekan radomski 30 XI 1864 do konsystorza sandomierskiego, spis majątku kościelnego $18 \mathrm{~V} 1865$.

${ }_{72}$ ArWł, sygn. KGK V 17, k. 176, 356, 393; Schem. Sandom. 1869-1872, passim.

${ }^{73}$ Schem. Sandom. 1869-1883, passim.

${ }^{74}$ „Kronika Diecezji Sandomierskiej”, 4 (1911) s. 243; Orzechowska, Własnośćc, s. 202. 
sióstr podtrzymywali dawne nabożeństwa zakonne. Bernardyni byli od lat kapelanami Bernardynek w Świętej Katarzynie. Funkcję tę w momencie kasaty pełnił o. Augustyn Czarnocki, o którym już wspomniano, że w 1866 r. przybył do klasztoru bernardynów w Paradyżu, a w Świętej Katarzynie zastąpił go o. Kazimierz Porowski. Pozostał on jako kapelan do zgonu, który nastąpił 18 czerwca 1888 r. $^{75}$ Po śmierci Porowskiego z klasztoru w Paradyżu został wysłany do Świętej Katarzyny 10 stycznia 1889 r. o. Tytus Rycerz. Jego wyjazd spotkał się z protestem dziekana, który pisał do biskupa, że w znacznie zmniejszonej w tym czasie obsadzie klasztoru w Paradyżu o. Tytus jest jedynym zakonnikiem zdolnym do głoszenia kazań i sprawowania uroczystych nabożeństw. Decyzja biskupa była jednak nieodwołalna: siostry też nie mogły pozostać bez kapelana, a nie było nikogo innego do dyspozycji ${ }^{76}$. O. Tytus pozostał w Świętej Katarzynie do śmierci 19 marca 1903 r., a więc jeszcze przez dziesięć lat po kasacie klasztoru w Paradyżu ${ }^{77}$.

Mówiąc o kapelanach, należy też wspomnieć o reformacie o. Janie Majewskim, który przebywał na Świętym Krzyżu jako ojciec duchowny mieszczącego się tam domu księży demerytów. Kasata klasztorów go nie dotknęła, ale w $1865 \mathrm{r}$. został wikariuszem w Bielinach, a ostatecznie sekularyzował się, przechodząc do diecezji sandomierskiej ${ }^{78}$.

\section{Proces przechodzenia w szeregi kleru diecezjalnego}

W chwili wykonywania ukazu kasacyjnego, o czym były już wzmianki, niektórzy zakonnicy przebywali poza klasztorami, najczęściej jako zastępujący lub wspomagający proboszczów, względnie pełniący obowiązki kapelanów przy klasztorach żeńskich czy też przy szpitalach. Po kasacie nasilił się proces przechodzenia do duszpasterstwa parafialnego. Niektórzy zakonnicy, spędziwszy dotychczas większą część życia zakonnego w pracy parafialnej, nie odnajdywali się w klasztorze, a po doświadczeniu kasaty parafia jawiła się im jako miejsce bezpieczniejsze, lub przynajmniej zapewniające większą stabilizację. Nie wszyscy poszukiwali miejsca w diecezji sandomierskiej: niektórzy woleli udać się do diecezji miejsca urodzenia lub do tej, w której mieli wielu znajomych księży lub z którą łączyły ich jeszcze jakieś więzy.

${ }^{75}$ ArSd, BernPar 1865-1877, protokół wizytacji klasztoru w Paradyżu 31 VIII 1866, uwagi wizytatora klasztorów z 22 VII 1867, Schem. Sandom. 1869-1889, passim.

${ }^{76}$ ArSd, BernPar 1871-1902, dziekan opoczyński 26 XII 1888/7 I 1889 do konsystorza sandomierskiego, konsystorz 29 XII 1888/10 I 1889 do dziekana, bp sandomierski 10 I 1889 do Rycerza, przełożony klasztoru w Paradyżu 11 I 1889 do konsystorza sandomierskiego.

${ }^{77}$ Schem. Sandom. 1904, s. 93; Klasztor Sióstr Bernardynek w Świętej Katarzynie. Klasztor pod Eysica. Dwa wieki pobytu Sióstr Bernardynek, Święta Katarzyna 2015.

${ }^{78}$ Schem. Sandom. 1869-1881, passim; „Przegląd Katolicki”, 18 (1880) s. 519; B. Stanaszek, R. Nowakowski, P. Tylec, Stownik biograficzny księży diecezji sandomierskiej XIX-XX w., t. 3, Sandomierz 2017, s. 18. 
Z klasztoru w Paradyżu odeszli do innych diecezji: w 1865 r. o. Benedykt Piotrowski do diecezji lubelskiej ${ }^{79}$, a o. Wiktoryn Sikorski do diecezji kieleckiej ${ }^{80}$, w 1867 r. o. Bronisław Chaciński do diecezji podlaskiej, również w 1867 r. o. Augustyn Czarnocki do diecezji kieleckiej, w 1868 r. o. Piotr Zbrożek do diecezji podlaskiej, w 1870 r. o. Teodor Więckowski do diecezji lubelskiej i w 1872 r. o. Rajmund Górzyński do diecezji podlaskiej.

Inkardynowani do diecezji sandomierskiej zostali następujący bernardyni: o. Joachim Nizner (indult sekularyzacyjny z 6 lipca 1866 r.), o. Gliceriusz Chybowski (indult sekularyzacyjny z 5 kwietnia 1867 r.), o. Filemon Kucharski (induIt sekularyzacyjny z 13 listopada 1867 r.), o. Martynian Maszewski (indult sekularyzacyjny także z 13 listopada 1867 r.), o. Jozafat Piotrowski (indult sekularyzacyjny z 9 września 1872 r.), o. Kandyd Stec (indult sekularyzacyjny z 1873 r.) i o. Edmund Mordziński (indult sekularyzacyjny z 1877 r.) ${ }^{81}$. Ponadto kleryk Faustyn Kamiński we wrześniu 1869 r. opuścił klasztor w Paradyżu, udając się do krewnych w okolice Łukowa na Podlasiu. Z wyżej wymienionych Nizner opuścił klasztor po otrzymaniu indultu sekularyzacyjnego i został administratorem parafii w Gierczycach, skąd w 1868 r. przeszedł na administratora do Łęgonic i tam zmarł 10 marca 1899 r. ${ }^{82}$ Chybowski otrzymał indult sekularyzacyjny, gdy przebywał już poza klasztorem: od grudnia 1864 r. pomagał duszpastersko w Końskich, stamtąd w 1869 r. przeszedł na administratora do Baćkowic, a w 1872 r. objął parafię w Wieniawie, gdzie zmarł 21 września $1890 \mathrm{r}^{83}$ Kucharski, wysłany w grudniu 1864 r. na zastępstwo do Żeleźnicy, pozostał w tej parafii jako administrator. Tam zmarł 5 grudnia $1880 \mathrm{r}^{84}$ Maszewski po otrzymaniu indultu sekularyzacyjnego objął w 1868 r. administrację parafii Bieliny, skąd w 1875 r. przeszedł na administratora parafii Stanowiska. Opuścił je 1891 r., przenosząc się do diecezji kujawsko -kaliskiej, w której został proboszczem w Białej koło Częstochowy. Tam zakończył życie 9 czerwca $1895 \mathrm{r}^{85}$ Piotrowski w 1868 r. został wikariuszem w Odrzywole, w 1872 r. został wikariuszem w Wysokiej, wreszcie w 1877 r. objął wikariat w Końskich. W 1884 r. wrócił do Wysokiej, ale jako administrator parafii,

${ }^{79}$ ArLb, sygn. 60 IIa 107, administrator diecezji lubelskiej 4 VII 1865 do policmajstra lubelskiego i 21 IX/3 X 1865 do Komisji Rządowej Spraw Wewnętrznych i Duchownych.

${ }^{80} \mathrm{ArKi}$, sygn. OK 1b, k. 568-573, 588-590, ArKi, sygn. XS-12, passim.

${ }^{81}$ Indulty sekularyzacyjne dla Niznera, Chybowskiego, Kucharskiego, Maszewskiego, Piotrowskiego i Steca zob.: ArSd, Sekul. 1835-1869. Indultu sekularyzacyjnego dla Mordzińskiego nie odnaleziono. O roku otrzymania sekularyzacji można wnioskować z tego, od kiedy Schem. Sandom. przestał zamieszczać przy jego nazwisku znak przynależności zakonnej.

${ }^{82}$ ArSd, BernPar 1865-1877, Lista osób zakonnych Zgromadzenia Ks.Ks. Bernardynów Klasztoru Wielko-Wolskiego [29 VIII 1866], uwagi wizytatora klasztorów z 31 VIII 1866 i 22 VII 1867; Schem. Sandom. 1869-1900, passim; Stanaszek, Nowakowski, Tylec, Stownik, t. 3, s. 96.

${ }^{83}$ ArSd, BernPar 1865-1877, protokół wizytacji klasztoru w Paradyżu 5 X 1865, uwagi wizytatora klasztorów z 22 VII 1867; Schem. Sandom. 1869-1891, passim; Stanaszek, Nowakowski, Stow$n i k$, t. 1, Sandomierz 2014, s. 119-120.

${ }^{84}$ Schem. Sandom. 1869-1881, passim; Stanaszek, Nowakowski, Stownik, t. 2, Sandomierz 2015, s. 171-172.

${ }^{85}$ Schematismus ecclesiarum et cleri dioecesis wladislaviensis pro anno Domini 1892-1896, [Włocławek 1891-1895], passim; Stanaszek, Nowakowski, Tylec, Słownik, t. 3, s. 40-41. 
skąd w 1887 r. przeszedł do Regowa. Przyczynił się do przeniesienia siedziby parafii z Regowa do Wysokiego Koła. Zmarł w Wysokim Kole 5 kwietnia 1899 r. ${ }^{86}$ Stec w chwili kasaty przebywał z pomocą duszpasterską w Skaryszewie, a do klasztoru już nie powrócił. Ze Skaryszewa przeszedł w 1867 r. na wikariat do Klimontowa, w 1871 r. został administratorem w Strzegomiu, skąd w 1873 r. przeszedł na wikariat do Rakowa, w 1875 r. do Odrowąża, a w 1876 r. został rektorem kościoła poreformackiego w Rytwianach. W 1878 r. objął administrację parafii Chobrzany, a w 1884 r. został administratorem w Tarczku. Zmarł w Tarczku 17 stycznia 1886 r. ${ }^{87}$ Mordzińskiw 1871 r. opuściłklasztor, zostając wikariuszem w Mninie, w 1873 r. objął wikariat w Radoszycach, w 1878 r. został administratorem w Bliżynie, skąd w 1883 r. przeszedł do Łukawy. Tam zmarł 3 września 1897 r. ${ }^{88}$

Faustyn Kamiński występuje w źródłach do 1893 r. Przez cały czas mieszkał u krewnych w Ryżkach koło Łukowa ${ }^{89}$. Biorąc pod uwagę posuwanie się w latach, należy przypuszczać, że w 1893 r. zakończył życie.

Czterech kleryków bernardynów po kasacie podjęło studia w seminarium duchownym w Sandomierzu i wszyscy doszli do kapłaństwa jako inkardynowani do diecezji sandomierskiej. Ich posługa kapłańska przypadła, gdy byli już duchownymi diecezji sandomierskiej, stąd też w artykule nie opisano ich losów; dla porządku wymieniono tylko ich nazwiska. Byli to: Bolesław (imię chrzestne Julian) Śliwiński, przyjęty w 1865 r., a wyświęcony w 1871 r. ${ }^{90}$, Grzegorz (imię chrzestne Szymon) Łukasik, przyjęty w 1867 r., a wyświęcony w 1868 r. ${ }^{91}$, Izaak (imię chrzestne Antoni) Kossakiewicz, przyjęty w 1867 r., a wyświęcony w 1873 r. ${ }^{92}$ i Bernardyn (imię chrzestne Wincenty) Iżyłowski przyjęty w 1868 r., a wyświęcony w $1869 \mathrm{r}^{93}$

Z klasztoru w Wysokim Kole do duszpasterstwa parafialnego przeszli: w archidiecezji warszawskiej o. Mikołaj Kalinowski, który opuścił klasztor 14 czerwca 1872 r. ${ }^{94}$, i o. Joachim Wierzbiłło, wyjeżdżając z Wysokiego Koła 8 maja 1876 r. ${ }^{95}$, w diecezji lubelskiej o. Walerian Olszewski, który opuścił klasztor

${ }^{86}$ „Przegląd Katolicki”, 37 (1899) s. 395-397; Stanaszek, Nowakowski, Tylec, Stownik, t. 3 , s. 171.

${ }^{87}$ ArSd, Sekul. 1835-1869, Stec 20 IX/2 X 1869 do bpa sandomierskiego; ArSd, BernPar 18651877, uwagi wizytatora klasztorów z 22 VII 1867; „Przegląd Katolicki”, 24 (1886) s. 123; Stanaszek, Nowakowski, Tylec, Stownik, t. 4, Sandomierz 2019, s. 80-81.

${ }^{88}$ ArSd, ZakPar 1872-1885, Mordziński 24 XII 1873/5 I 1874 do bpa sandomierskiego; Stanaszek, Nowakowski, Tylec, Stownik, t. 3, s. 74-75.

${ }^{89}$ Schematismus ecclesiarum et cleri dioecesis lublinensis pro anno Domini 1870-1893, [Lublin 1869-1892], passim.

${ }^{90}$ Stanaszek, Nowakowski, Tylec, Stownik, t. 4, s. 148-149.

${ }^{91}$ Tamże, t. 2, s. 224.

${ }^{92}$ Tamże, s. 122.

${ }^{93}$ Tamże, s. 18.

${ }^{94}$ ArSd, RefWK 1870-1893, Kalinowski 15/27 IV 1871 i 26 V/7 VI 1871 do wizytatora klasztorów, ukaz Kolegium Duchownego w Petersburgu z 3 IV 1872, wizytator klasztorów 5 VII 1872 do konsystorza sandomierskiego.

${ }^{95}$ ArSd, RefWK 1870-1893, administrator archidiecezji warszawskiej 27 III 1876 do bpa sandomierskiego, przełożony klasztoru 29 IV/11 V 1876 do konsystorza sandomierskiego. 
25 maja 1871 r.. ${ }^{96}$, i o. Sylwester Krombach, który wyjechał z Wysokiego Koła w 1875 r. ${ }^{97}$ Tylko jeden zakonnik podjął pracę w diecezji sandomierskiej. Był to o. Ignacy Bisikiewicz, który w 1881 r. otrzymał indult sekularyzacyjny i został wikariuszem w Sieciechowie, skąd w 1882 r. przeszedł na wikariat do Iłży, a w 1883 r. na wikariat do Słupi Nowej z rezydencją przy kościele pobenedyktyńskim na Świętym Krzyżu. W 1886 r. został rektorem kościoła poreformackiego w Rytwianach i na tym stanowisku zmarł 30 czerwca 1889 r. ${ }^{98}$

Dwóch reformatów kasata zastała, gdy przebywali z posługą duszpasterską w parafiach. O. Jakub Burzyński zastępował proboszcza w Siennie i pozostał w tej parafii do 1872 r. W tymże roku uzyskał indult sekularyzacyjny i został administratorem parafii Bogoria. W Bogorii pozostał do zgonu 27 lutego 1889 r. ${ }^{99} \mathrm{~W}$ pracy duszpasterskiej w Zwoleniu pomagał o. Dominik Pełech (Pelech). W 1867 r. przeszedł ze Zwolenia do Rakowa, w 1868 r. do Iwanisk, a stamtąd udał się na kapelana sióstr szarytek w Kobylanach i tam też zmarł 2 września 1869 r. ${ }^{100}$

Wyżej wzmiankowano o kapelanie domu księży demerytów na Świętym Krzyżu, reformacie o. Janie Majewskim. W 1866 r. Majewski przeszedł z Bielin na wikariat do Solca, a w 1867 r. do Waśniowa. Indult sekularyzacyjny uzyskał w 1872 r. W 1875 r. został administratorem w Słupi Nadbrzeżnej, a w 1880 r. objął rektorat kościoła pobenedyktyńskiego na Świętym Krzyżu i tam zmarł 6 lipca 1880 r. $^{101}$

W diecezji sandomierskiej po kasacie nie ostał się żaden klasztor Franciszkanów konwentualnych, niemniej jednak dwóch franciszkanów podjęło pracę w duszpasterstwie parafialnym, a jeden tylko znalazł się na terenie diecezji. W $1866 \mathrm{r}$. przybył z klasztoru w Kaliszu o. Roman Jardel i został wikariuszem w Połańcu. Tam zmarł 15 grudnia 1868 r. ${ }^{102} \mathrm{~W} 1873$ r. również z Kalisza przybył o. Gentilis Parczewski. Początkowo został wikariuszem w Iłży, od 1875 r. był wikariuszem w Ciepielowie. W 1878 r. został administratorem w Zemborzynie, skąd w 1889 r. przeszedł do Grzgorzewic. Zmarł w Grzegorzewicach 10 listopada 1896 r. ${ }^{103}$ W 1884 r. przybył kolejny zakonnik z Kalisza, o. Alfons Mazurkiewicz. Nie pod-

${ }^{96}$ ArSd, RefWK 1870-1893, konsystorz lubelski 21 I 1871, 8 III 1871 i 4 IX 1872 do konsystorza sandomierskiego, konsystorz sandomierski 26 I/7 II 1871 i 6/18 III 1871 do konsystorza lubelskiego.

${ }^{97}$ ArSd, RefWK 1870-1893, wizytator klasztorów 24 III/5 IV 1875 do bpa sandomierskiego, przełożony klasztoru 29 VII/5 VIII 1875 do konsystorza sandomierskiego.

${ }^{98}$ Schem. Sandom. 1882-1890, passim; „Przegląd Katolicki”, 19 (1881) s. 530; Stanaszek, Nowakowski, Stownik, t. 1, s. 62.

${ }^{99}$ Schem. Sandom. 1869-1890, passim; Stanaszek, Nowakowski, Stownik, t. 1, s. 97.

${ }^{100}$ Schem. Sandom. 1869-1870, passim; Stanaszek, Nowakowski, Stownik, t. 3, s. 152.

${ }_{101}$ Schem. Sandom. 1869-1881, passim; „Przegląd Katolicki”, 18 (1880) s. 519; Stanaszek, Nowakowski, Tylec, Stownik, t. 3, s. 18.

${ }^{102}$ ArWł, sygn. KGK II 12, k. 946-949; Schem. Sandom. 1869, s. 58.

${ }^{103}$ ArWł, sygn. KGK V 17, k. 177. 437; Schem. Sandom. 1874-1897, passim; Stanaszek, Nowakowski, Tylec, Stownik, t. 3, s. 141-142. 
jął jednak pracy duszpasterskiej, a przebywał jako rezydent u krewnych w Siennie. Nie udało się ustalić jego dziejów, bo od 1889 r. nie występuje w źródłach ${ }^{104}$.

W diecezji sandomierskiej podjęło też pracę duszpasterską dwóch kapucynów. W 1868 r. przybył z klasztoru w Nowym Mieście nad Pilicą o. Bonawentura Rewrowski. Początkowo był nieformalnym wikariuszem w Klwowie. W 1874 r. otrzymał indult sekularyzacyjny. W 1875 r. został wikariuszem katedry w Sandomierzu, a w 1876 r. przeszedł na wikariat do kolegiaty w Opatowie. W 1879 r. objął administrację parafii Wiśniowa i pozostał tam do śmierci. Zmarł 26 stycznia 1901 r. ${ }^{105} \mathrm{~W} 1871$ r. z klasztoru w Łomży przybył o. Celestyn Adamski. Początkowo zamieszkał u krewnych w Wyśmierzycach, ale wkrótce przeniósł się do Tczowa. W 1877 r. został wikariuszem katedralnym i zarazem spowiednikiem w seminarium duchownym, a w 1879 r. przeszedł na wikariat do Gór Wysokich. W 1881 r. objął wikariat (a właściwie rektorat) kościoła pofranciszkańskiego w Zawichoście i tegoż roku otrzymał indult sekularyzacyjny. Zmarł w Zawichoście 17 kwietnia 1902 r. ${ }^{106}$

$* * * * *$

Kasata klasztorów w Królestwie Polskim miała za zadanie stopniową likwidację życia zakonnego. Władzom carskim w dużym stopniu udało się ten zamiar zrealizować. W diecezji sandomierskiej ostatni klasztor franciszkański - bernardynów w Paradyżu - został skasowany w 1893 r. W 1899 r. zmarli dwaj ostatni sekularyzowani zakonnicy, o. Joachim Nizner i o. Jozafat Piotrowski, ale nie należeli już w tym czasie do duchowieństwa zakonnego, byli jedynie świadkami kasaty klasztorów. W 1911 r., ze śmiercią o. Filipa Jóźwika, zakończyła się obecność zakonników na stanowiskach rektorów kościołów poklasztornych i zarazem obecność zakonników franciszkańskich w diecezji. Odrodzenie życia zakonnego w diecezji sandomierskiej nastąpiło dopiero po I wojnie światowej.

\section{REFERENCES / BIBLIOGRAFIA}

\section{Źródła}

Archiwum Archidiecezjalne w Lublinie

sygn. 60 IIa 107.

sygn. 60 XI 33.

${ }^{104}$ ArWł, sygn. KGK V 17, k. 116, 524, 527; ArWł, sygn. KGK V 25, k. 253, 257, 323, 325; Schem. Sandom. 1885-1890, passim.

${ }^{105}$ Archiwum Warszawskiej Prowincji Kapucynów w Zakroczymiu (dalej ArKapWwa), sygn. AKN 1-VI-1, t. 4, k. 228v-231v, 240-242; ArKapWwa, sygn. AKN 2-II-1, t. 3, k. 102-103v, $118-$ 118v; Schem. Sandom. 1871-1902, passim; „Przegląd Katolicki”, 17 (1879) s. 395; J. L. Gadacz, Słownik polskich kapucynów, t. 2, Wrocław 1986, s. 216; Stanaszek, Nowakowski, Tylec, Słownik, t. 3 , s. 225.

${ }^{106}$ ArKapWwa, sygn. APW 1-IV-9, k. 7; Schem. Sandom. 1874-1905, passim; „Przegląd Katolicki”, 17 (1879) s. 197; 19 (1881) s. 419; J.L. Gadacz, Stownik, t. 1, Wrocław 1985, s. 254-255; Stanaszek, Nowakowski, Stownik, t. 1, s. 13. 
Archiwum Diecezjalne w Kielcach

sygn. OK $1 b$.

sygn. OK $20 / 7$.

sygn. XS-12.

Archiwum Diecezjalne w Sandomierzu

bez sygn., Akta Konsystorza Jeneralnego Dyecezyi Sandomierskiej Kościoła Wniebowzięcia NMP w Opatowie 1865-1983.

bez sygn., Akta Konsystorza Jeneralnego Dyecezyi Sandomierskiej Ks.Ks. Reformatów w Wysokim Kole 1870-1893.

bez sygn., Akta Konsystorza Jeneralnego Dyecezyi Sandomierskiej t. s. Klasztoru XX. Bernardynów w Wielko-Woli 1871-1902.

bez sygn., Akta Konsystorza Jeneralnego Dyecezyi Sandomierskiej Zakonników wysyłanych na parafije 1872-1885.

bez sygn., Akta kościoła św. Katarzyny w Radomiu 1865-1936.

bez sygn., Akta sekularyzacyi zakonników 1835-1869.

bez sygn., Akta wizytatora klasztorów Dyecezyi Sandomierskiej t. s. Klasztoru XX. Bernardynów w Wielko-Woli 1865-1877.

bez sygn., Akta wizytatora klasztorów Dyecezyi Sandomierskiej t. s. Klasztoru OO. Reformatów w Wysokim Kole 1864-1878.

Archiwum Diecezjalne we Włocławku

sygn. KGK II 12.

sygn. KGK V 17.

sygn. KGK V 23.

sygn. KGK V 25.

Archiwum Warszawskiej Prowincji Kapucynów w Zakroczymiu

sygn. AKN 1-VI-1, t. 4.

sygn. AKN 2-II-1, t. 3.

sygn. APW 1-IV-9.

„Kronika Diecezji Sandomierskiej”, 4 (1911).

„Przegląd Katolicki”, 17 (1879); 18 (1880); 19 (1881); 24 (1886); 37 (1899).

Schematismus ecclesiarum et cleri dioecesis lublinensis pro anno Domini 1870-1893, [Lublin 1869-1892].

Schematismus ecclesiarum et cleri dioecesis sandomiriensis pro anno Domini 1864, 1869 1912 [Sandomierz 1863, 1868-1911].

Schematismus ecclesiarum et cleri dioecesis wladislaviensis pro anno Domini 1892-1896, [Włocławek 1891-1895].

Schematismus Patrum et Fratrum necnon Monialium Ordinis Minorum S.P.N. Francisci regularis observantiae vulgo Bernardinorum Provinciae Minoris Poloniae pro anno Domini 1863, [Warszawa 1863].

\section{Opracowania}

Budziarek Marek, Realizacja ukazu cesarskiego z 8 XI 1864 wobec klasztoru kapucynów $w$ Lublinie, w: Zakony franciszkańskie w Polsce, t. 3: Franciszkanie w Polsce XIX wieku, Niepokalanów 1996, s. 163-176. 
Gach Piotr P., Kasaty zakonów na ziemiach dawnej Rzeczypospolitej i Śląska 1773-1914, Lublin 1984.

Gach Piotr P., Zakony franciszkańskie na ziemiach dawnej Rzeczypospolitej i Śląska w latach 1773-1914, w: Zakony franciszkańskie w Polsce, t. 3: Franciszkanie w Polsce XIX wieku, Niepokalanów 1996, s. 11-56.

Gadacz Jan L., Słownik polskich kapucynów, t. 1, Wrocław 1985, t. 2, Wrocław 1986.

Gajewski Stanisław, Kasata klasztorów w diecezji lubelskiej w roku 1864, „Roczniki Humanistyczne", 21 (1973) z. 2, s. 351-390.

Grudziński Kajetan, Opatów, w: Klasztory bernardyńskie w Polsce w jej granicach historycznych, red. H.E. Wyczawski, Kalwaria Zebrzydowska 1985, s. 239-244.

Grudziński K., Radom, w: Klasztory bernardyńskie w Polsce w jej granicach historycznych, red. H.E. Wyczawski, Kalwaria Zebrzydowska 1985, s. 293-301.

Grzybowski Michał M., Postawa Wincentego Chościak-Popiela, biskupa płockiego, wobec kasaty klasztorów z 1864 r. w jego diecezji, „Studia Płockie”, 11 (1983) s. 257272.

Iriarte Lázaro, Historia franciszkanizmu, Kraków 1998.

Kalinowski Zenon, Kościót św. Józefa w Sandomierzu, cz. 2, Działalność duszpasterska reformatów sandomierskich i dzieje kościoła od kasaty klasztoru w r. 1864, „Studia Sandomierskie", 4 (1983-1984) s. 320-321.

Kałowski Julian, Uprawnienia nad zakonami udzielone biskupom przez Stolice Apostolska po 1864 r., „Prawo Kanoniczne”, 20 (1977) nr 1-2, s. 137-149.

Klasztor Sióstr Bernardynek w Świętej Katarzynie. Klasztor pod Łysica. Dwa wieki pobytu Sióstr Bernardynek, Święta Katarzyna 2015.

Orzechowska Elżbieta, Własność poklasztorna w diecezji sandomierskiej po ukazie z 8 XI 1864 r., „Roczniki Humanistyczne”, 31 (1983) z. 2, s. 187-212.

Orzechowska Elżbieta, Z działalności patriotycznej bernardynów w Radomiu w dobie powstania styczniowego (1861-1864), w: Zakony franciszkańskie w Polsce, t. 3: Franciszkanie w Polsce XIX wieku, Niepokalanów 1996, s. 149-161.

Pabin Andrzej, Paradyż, w: Klasztory bernardyńskie w Polsce w jej granicach historycznych, red. H.E. Wyczawski, Kalwaria Zebrzydowska 1985, s. 251-254.

Petrani Aleksy, Kasata domów zakonnych w Warszawie w 1864 roku w świetle źródet rosyjskich, „Prawo Kanoniczne”, 15 (1972) nr 1-2, s. 267-275.

Prejs R., Rektorzy kościołów pofranciszkańskich. Z dziejów zakonników Królestwa Polskiego po kasacie 1864 r., „Studia Franciszkańskie” 9 (1998), s. 125-154.

Prejs Roland, Bernardyni prowincji małopolskiej po kasacie 1864 r., „Studia Franciszkańskie", 10 (1999) s. 327-372.

Prejs Roland, Klasztor bernardynów w Paradyżu (Wielkiej Woli) w latach 1864-1893. Przykład funkcjonowania klasztoru etatowego $w$ Królestwie Polskim $w$ warunkach pokasacyjnych, „Studia Franciszkańskie”, 11 (2001) s. 275-305.

Prejs Roland, Zakonnicy franciszkańscy Królestwa Polskiego po kasacie 1864 roku. Dzieje-postawy, Warszawa 2003.

Prejs Roland, Słownik biograficzny zakonników franciszkańskich Królestwa Polskiego po kasacie 1864 r. Poznań 2004.

Prejs Roland, Bernardyni w Królestwie Polskim po kasacie 1864 r., w: Pięćset pięćdziesiąt lat obecności oo. Bernardynów w Polsce (1453-2003), red. W.F. Murawiec, D.A. Muskus, Kalwaria Zebrzydowska 2006, s. 427-513.

Prejs Roland, Klasztor bernardynów w Radecznicy w latach 1864-1919, w: Na tym miejscu chwała Boga Najwyższego odprawiać się będzie... W setna rocznicę rewindykacji 
klasztoru oo. Bernardynów w Radecznicy (1919-2019), red. I.M. Janusz, A.K. Sitnik, Kalwaria Zebrzydowska 2019, s. 117-132.

Stanaszek Bogdan, Nowakowski Ryszard, Słownik biograficzny księży diecezji sandomierskiej XIX-XX w., t. 1, Sandomierz 2014.

Stanaszek Bogdan, Nowakowski Ryszard, Słownik biograficzny księży diecezji sandomierskiej XIX-XX w., t. 2, Sandomierz 2015.

Stanaszek Bogdan, Nowakowski Ryszard, Tylec Piotr, Słownik biograficzny księży diecezji sandomierskiej XIX-XX w., t. 3, Sandomierz 2017.

Stanaszek Bogdan, Nowakowski Ryszard, Tylec Piotr, Słownik biograficzny księży diecezji sandomierskiej XIX-XX w., t. 4, Sandomierz 2019.

Szteinke Anzelm J., Kościót Świętego Antoniego i klasztor Franciszkanów-Reformatów w Warszawie 1623-1987, Kraków 1990.

Wiśniewski Jan, Dekanat opoczyński, Radom 1913.

Wójcik Walenty, Tak zwana reforma klasztorów w 1864 roku na terenie diecezji sandomierskiej, „Archiwa Biblioteki i Muzea Kościelne”, 23 (1971) s. 343-360.

Wyczawski Hieronim E., Krótka historia Zakonu Braci Mniejszych, w: Klasztory bernardyńskie w Polsce w jej granicach historycznych, red. H.E. Wyczawski, Kalwaria Zebrzydowska 1985, s. 581-631.

\title{
THE DISAPPEARANCE OF THE PRESENCE OF FRANCISCAN MONKS IN THE SANDOMIERZ DIOCESE AFTER 1864
}

\begin{abstract}
Tsarist authorities dissolved monasteries in the Kingdom of Poland in 1864. The monasteries of the Observantes (Bernardines) in Kazanów, Opatów and Radom, the Conventual Fran-ciscans in Smardzewice and Zawichost and the Reformers Franciscans in Rytwiany, Sandom-ierz and Solec were closed in the diocese of Sandomierz. The Observante (Bernardine) monastery in Paradyż (Wielka Wola) was not closed. In 1870, the tsarist authorities relocated the Reformers Franciscans from the monastery in Jędrzejów (Kielce diocese) to the monastery in Wysokie Koło. Thus, in the diocese there were ultimately two Franciscan monasteries preserved from dissolution: the Bernardines in Paradyż and the Reformers Franciscans in Wysokie Koło. The number of monks systematically decreased, mainly due to deaths, the ban on admitting novices and the transfer of some monks to pastoral work in parishes. This meant that the monastery in Wysokie Koło ceased to exit along with the death of the last monk in 1891, and the monastery in Paradyż was shut in 1893. In 1899, two former Bernardines died, who at that time were secularised and worked in the parish ministry as priests of the Sandomierz diocese. The presence of former religious who had been secularised ended there. At the churches of the monasteries closed in 1864, the tsarist authorities left one or two monks to celebrate the services. The last of such friars died in 1911, and that is when the presence of Franciscan friars in the diocese of Sandomierz ended.
\end{abstract}

Keywords: dissolution of monasteries; Diocese of Sandomierz; Observantes (Bernardines); Conventual Franciscans; Reformers Franciscans 